\title{
The Effects of Religiosity and Attitude on Consumer Boycotts
}

\section{Zalinawati Abdullah, Marhana Mohamed Anuar, Mohd Rafi Yaacob}

To Link this Article: http://dx.doi.org/10.6007/IJARBSS/v11-i18/11432 $\quad$ DOI:10.6007/IJARBSS/v11-i18/11432

Received: 25 August 2021, Revised: 30 September 2021, Accepted: 10 October 2021

Published Online: 24 October 2021

In-Text Citation: (Abdullah et al., 2021)

To Cite this Article: Abdullah, Z., Anuar, M. M., \& Yaacob, M. R. (2021). The Effects of Religiosity and Attitude on Consumer Boycotts. International Journal of Academic Research in Business and Social Sciences, 11(18), 133-150.

Copyright: (C) 2021 The Author(s)

Published by Human Resource Management Academic Research Society (www.hrmars.com)

This article is published under the Creative Commons Attribution (CC BY 4.0) license. Anyone may reproduce, distribute, translate and create derivative works of this article (for both commercial and non-commercial purposes), subject to full attribution to the original publication and authors. The full terms of this license may be seen

at: http://creativecommons.org/licences/by/4.0/legalcode

Special Issue Title: TiBECVII 2021, 2021, Pg. 133 - 150

Full Terms \& Conditions of access and use can be found at http://hrmars.com/index.php/pages/detail/publication-ethics 


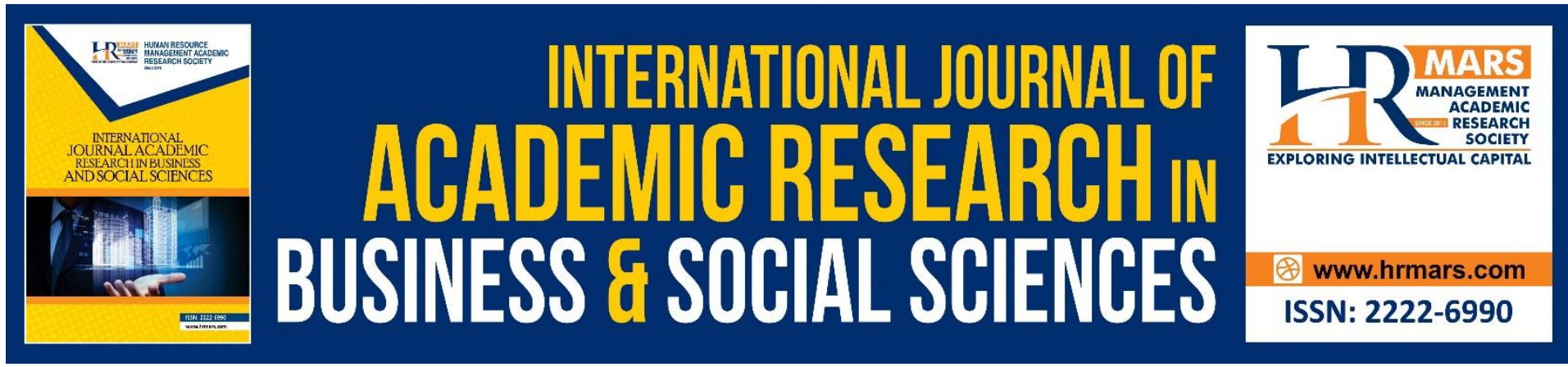

\title{
The Effects of Religiosity and Attitude on Consumer Boycotts
}

\section{'Zalinawati Abdullah, ${ }^{2}$ Marhana Mohamed Anuar, ${ }^{3}$ Mohd Rafi Yaacob}

${ }^{1}$ Faculty of Business Management, Universiti Teknologi MARA Cawangan Terengganu, Malaysia, ${ }^{2}$ Faculty of Business, Economics and Social Development, Universiti Malaysia

Terengganu, Malaysia, ${ }^{3}$ Faculty of Entrepreneurship and Business, Universiti Malaysia

Kelantan, Malaysia

Email: marhana@umt.edu.my

\begin{abstract}
Boycott is one of the manners in which consumers portray their hatred or disagreement with companies' corporate social responsibility (CSR) policies and practices and thus is unwelcome by companies. In spite of the massive rise in consumer boycotts, marketing pays little attention to this issue. Addressing this deficiency, this study uses the value-attitudebehaviour model to examine how religiosity and attitude affect consumer boycotts. The sample used in this study is the Malaysian consumer, with a total of 330 respondents. Data for this study was collected using an online survey and analysed using partial least square structural equation modelling. The findings discover that consumer's religiosity and attitude positively influence consumer boycotts. The study also revealed that attitude plays a mediating role between religiosity and consumer boycotts. This study has made significant contributions to both theory and practice. From a theoretical perspective, this study fills in the literature gaps and enhances understanding on how religiosity and attitude affect consumer boycotts. This article provides insights to improve companies' CSR practices and policies to avoid consumer boycotts in the future.
\end{abstract}

Keywords: Religiosity, Attitude, CSR, Consumer Boycott, Value-Attitude-Behaviour Model.

\section{Introduction}

There are studies show that consumers are increasingly concerned about the environment, for example, with a large number of consumers in the United Kingdom agreeing to reject brands that affect the environment in order to achieve long-term sustainability (Kantar, 2019). It is not impossible for consumers to expect more from the brand, and at the level of individual action, people are more willing to boycott the brand. In addition, Kantar (2019) argues that 924 (77\%) out of 1,200 consumers are willing or likely to consider switching brands, avoiding or boycotting certain products on the basis of brand sustainability and environmental policies. Due to growing pressure from consumers on companies to embrace corporate social responsibility (CSR), companies worldwide have adopted CSR to stay competitive in business. The right CSR initiatives are able to provide sustainable competitive 
advantage for companies. Nevertheless, CSR activities that are perceived as unethical may tarnish companies' image and reputation (Strahilevitz, 2003; Zeng, Audrain-Pontevia \& Durif, 2020). Today, consumer boycotts are more prevalent as many consumers are aware that they can boycott companies that act against their beliefs (Zeng, Audrain-Pontevia \& Durif, 2020). According to an online consumer survey by GMIPoll, 36\% out of 15,500 consumers from 17 countries in 2005 indicated that they had boycotted at least one brand (Holmes, 2005). Amongst the boycotted brands were Nike, Coca-Cola, Facebook, McDonald's, Adidas, L'Oreal, HSBC, Sony and Nestle (Abdul-Talib, Abd-Latif \& Abd-Razak, 2016; Wexler, 2021; Holmes, 2005). The most enthusiastic boycotters are the Chinese, with majority of the respondents refused to buy products from certain manufacturers; while Danish (49\%); French (46\%); Japanese (20\%); and Mexican (15\%) avoided certain brands (Holmes, 2005). The most frequently cited reasons for boycotting were unfair labour practices (e.g., ASDA Walmart, Cadbury, Coca-Cola; unsafe products (e.g., Nestle, Mc Donalds); and unhealthy products (e.g., Nestle, Coca-Cola). Other reasons for boycotting include inhumane act/human rights (e.g., Facebook, Puma, Nestle); animal rights (e.g., Coca-Cola, L'Oreal, Hermes's); bad publicity, environment concern (e.g., British Petroleum, Kellogg's); and country origination (AbdulTalib, Abd-Latif \& Abd-Razak, 2016; Wexler, 2021; Villanueva, 2020).

In year 2020, the University of Chicago released a major report on child labour and revealed that $43 \%$ of children living in cocoa producing areas are involved in the workforce due to certain reasons; 1 ) poverty, and 2) higher labour cost of employing adult labourers (Ethical Consumer Research, 2021). There have been many boycott campaigns in Malaysia for various reasons, such as immoral behaviour (Regencia, 2019; Safak, 2019). Muslims also call for a boycott of Israeli, American (Fakriza \& Nurdin, 2019) and France products (Tee, 2020). It is believed that the boycott among Muslim consumers is closely linked to religious reasons. Exploitation of religious symbols or any symbols may trigger a boycott participation among religious believers (Jensen, 2008). In Malaysia, religiosity and attitude are very influential factors in various aspects of people's lives. Malaysia's population in 2019 was 32.7 million people in which Islam is the most widely practiced religion at $63.3 \%$ and followed by Buddhism (19.8\%), Christianity (9.2\%), Hinduism (6.5\%), other religions (1.7\%) and atheism or unknown religion is $0.5 \%$. Other religions include the Chinese religion, the Sikh religion, Judaism, and others (Malaysia Official Statistic, 2020). One of the roles of religion is to provide a direction and meaningful goal to what people undertake (Peterson \& Roy, 1985). In addition, religiosity can influence the life of a person, the choices they make as well as what they consume (Fam et al., 2004). It has shown that the issue of consumer boycott due to international crises is not a new phenomenon in the marketing field (Abd-Razak \& AbdulTalib, 2012). There have been many boycott campaigns in Malaysia held for various reasons, such as immoral behaviour (Regencia, 2019; Safak, 2019).

Consumers have the power to either reward or punish companies. Consumers may punish companies by boycotting companies with poor CSR activities and reward companies with good CSR activities. Boycott is considered as a significant means for consumers to express their dissatisfaction with companies' economic and social factors (e.g., price, unsafe products, unhealthy products, inhumane act, human rights). Recently, boycotting is the greatest weapon for consumers. Since it leads the company to undergo major losses, it is possible that more serious things would happen, such as loss of sales, reduce brand loyalty (Fakriza \& Nurdin, 2019) and bankruptcy. Nevertheless, many consumer boycotts are not to punish companies but to change companies behaviour and practices towards ethical business 
practices. Despite a growing interest on boycott's and its critical importance in today's competitive business environment, consumer boycott is still underexplored (Cromie \& Ewing, 2009; Lee et al., 2009) and thus research that focused on this issue remains scarce (Zeng et al., 2020; Hoffmann \& Múller, 2009). In addition, evidence of religiosity and attitude influence on boycott participation have not been fully addressed, especially from the standpoint of Malaysian consumers. Based on the value-attitude-behaviour (VAB) model (Homer \& Kahle, 1988), this study tries to answer the following research questions: (a) How religiosity and attitude affect consumer boycotts?, (b) Does attitude mediates the relationship between religiosity and consumer boycotts? This study seeks to fill in the literature gap by examining how religiosity and attitude affect consumer boycotts as well as to assess the mediating role of attitude between religiosity and consumer boycotts. This study provides significance contributions to both theory and practice. For theoretical significance, this study enhances understanding on the effect of religiosity and attitude on consumer boycotts. From a managerial significance, the findings provide guidelines to help managers and policy makers to improve their CSR implementations that would help their companies to gain sustainable competitive advantage.

\section{Literature Review}

\section{Determinants of Consumer Boycotts}

Consumer boycotts can be defined as an act in which one or more parties want to achieve certain objectives by urging consumers to refrain from making selected purchases in the marketplace (Friedman, 1985). Thus, it can be said that consumer boycotts are a form of modest, nonviolent action against economics, political, and social injustices that are conducted in the marketplace (Sasson, 2016). They can be seen as collective actions to confront the corporation to coerce corporate change (Yang \& Rhee, 2020). Consumer boycotts express severe consumer dissatisfaction with a firm (Shaw \& Newholm, 2002) and are recognized as catalyst for social and economic change. Research has shown that they can have dramatic consequences for companies, such as negative effects on stock price and impacting company's image (Luo, Zhang \& Marquis, 2016; Omar et al., 2019). Boycotting is also known as anti-consumption behaviour (Sen, Gurhan-Canli \& Morwitz, 2001; Yuksel, 2013; Yuksel \& Mryteza, 2009). Consumer boycott could be defined as an expression of animosity that results in an unwillingness to make selected purchases in the market due to various reasons such as military violence, political injustice, economic inequality practices or a firm's irresponsible behaviour (Abd-Razak \& Abdul-Talib, 2012). There are two categories of consumer boycott and these include micro boycott that refers to boycott towards a firm and macro boycott that describes a boycott towards a country (Friedman, 1999; Klein, et al., 2004). Boycott is a consumer's volunteer action of not purchasing a certain product from a certain company or country altogether. Boycott is also the individual result of boycott campaigns that can target either a specific company or all companies of a given country (Abosag, 2010).

\section{Religiosity}

Religion is an organized system of beliefs, practices, rituals and symbols, which allows one to be closer to the sacred or the transcendent (God, a supreme power, ultimate reality or truth), and to understand one's own responsibility and relation to others in a community (Koening et al., 2000). More simple and precise religiosity is defined as "individual preferences, emotions, beliefs, and actions that refer to an existing (or self-made) religion" (Stolz, 2009, p. 
347). The definition of religiosity from consumers' perspective, is "the degree of being religious" (Cyril De Run et al., 2010). Religion is a part of a culture, and significantly influence the peoples' systems of values and habit. On the other hand, religion also influences their lifestyle such as dictates their buying decision and consumption behavior (Dekhil, Jridi \& Farhat, 2017). Furthermore, they found that highly religious people are more likely to be involved in boycotting a brand, and this result is consistent with the findings of Al-Hyari et al (2012). Furthermore, Giorgi and Marsh (1990) found that religion and the degree of religiosity of individuals have a positive effect on their moral behaviors and this is in line with Farah (2014) who showed that religiosity significantly motivates boycott and the way consumers perceive the brand image, which will then affect the way consumers judge these products. Abou-Youssef et al., (2015) stated that religion shapes attitudes and how religiosity grows are of inquiry. In addition, numerous social studies have shown that religion has a positive effect on people's lives (Abou-Youssef et al., 2015) and several studies have also shown that religion affect consumer attitudes and behaviour (Armstrong, 2001; Arnould, Price \& Zikhan, 2004; Burkett, 1980; Cochran and Cohen, 1983; Delener, 1994; Hawks and Bahr, 1992; Matitila et al., 2001; Pettinger et al., 2004).

\section{Attitude}

In this study, attitude refers to attitude towards responsible companies. One of the essential aspects of attitudes is that they have been learned (Abou-Yousseff et al., 2015). In the marketing context, the attitudes which have a link with purchasing behaviours, actual experience and product testing. Attitudes have a motivational factor, as they may lead consumers to certain actions or may jeopardize certain behaviours (Fazio, 1986; Schiffman and Kanuk, 2000). In addition, consistent with VAB model, attitude is projected to mediate the relationship between religiosity value and boycott participation.

\section{Theoretical Framework and Hypotheses Development}

A deeper understanding of the consumer decision-making process in the context of boycotts is crucial. Among the various expressions of socially responsible consumption, boycotting has been considered to be "the most deliberate form of ethical purchase behaviour" (Delistavrou et al., 2019; Smith, 1987). Following this meaningful insight, it is proposed that boycotting is a form of socially responsible consumption. In the case of boycotting, a consumer who participates in the boycotting campaign is involved in a problem-solving process. This behaviour is, by nature, a case of value-attitude-behaviour cognitive hierarchy. Therefore, the VAB model (Homer \& Kahle, 1988) was considered as the appropriate theoretical framework to study consumer boycott. In social psychology and marketing studies, the VAB model has been widely used to understand behaviour (e.g., Kang, Jun \& Arendt, 2015; Honkanen et al., 2006; Vaske \& Donnelly, 1999). Based on the VAB model, value-attitude-behaviour are organized in cognitive hierarchy sequence, in which values influence behaviour indirectly through attitudes. Homer and Kahle (1988) found causal sequence from abstract cognitions (i.e., values) to mid-range cognitions (i.e., attitudes) to specific behaviours. Applying the VAB model in the context of this study, it is proposed that religiosity (value) influences boycotts (behaviour) through attitude towards responsible companies (attitude). With reference to the VAB model, the following theoretical framework and hypotheses were proposed for this study: 


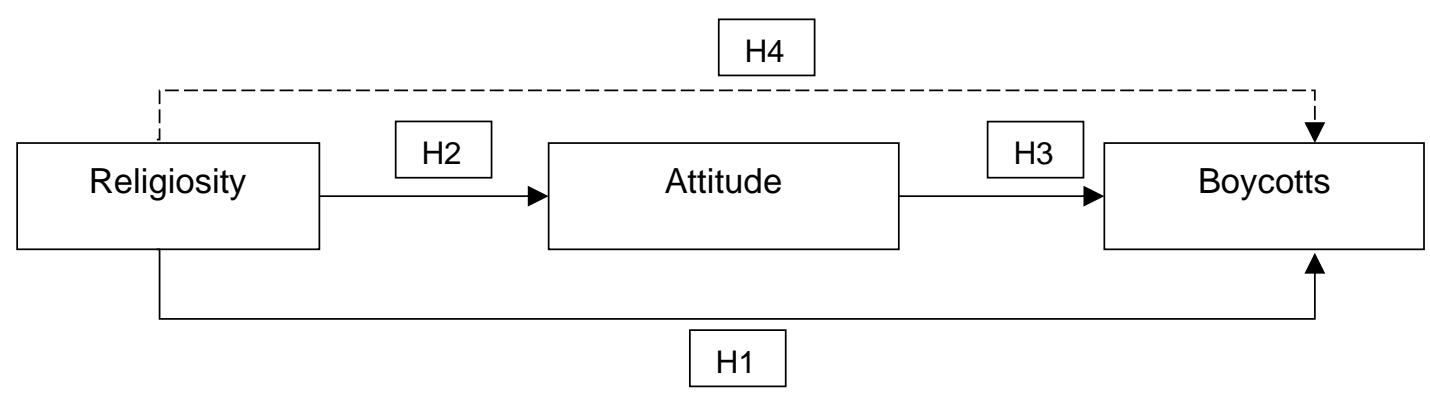

Figure 1: Research Framework

Therefore, based on the VAB model and past literature, the following hypotheses were developed:

H1 Religiosity has a positive influence on consumer boycotts

$\mathrm{H} 2$ Religiosity has a positive influence on attitude

H3 Attitude has a positive influence on consumer boycotts

$\mathrm{H} 4$ Attitude mediates the relationship between religiosity and consumer boycotts

\section{Methodology}

Sampling technique and sample size determination

A quantitative research with a convenience sampling method was used in this study and this sampling is highly recommended due to the target population being unknown (Hulland et al., 2017). The survey data was collected through the online survey questionnaire that was presented in the Google Forms format and made available via an internet connection within a month. This study utilized G*Power 3.1.9.2 software to reach the minimum sample size needed. The sample size necessary for one independent variable and two dependent variables using effect size $\left(\mathrm{f}^{2}\right)$ of 0.15 (medium) is 107 respondents. However, a total of 330 questionnaires were collected from Malaysian consumers.

\section{Measurement Items}

The distributed questionnaire consists of four sections. The instruments involving 14 items related to the research framework were adopted from existing literature and refined based on the context of this study. In section A, the respondents were asked about boycott participation that was adopted from Farah (2014), boycotting unsafe products, unhealthy products from companies or certain countries that support inhuman activities and the way to express his/her anger to them with five items by using seven-point Likert-scale (1= strongly disagree and $7=$ strongly agree). In section $B$, the religiosity (value) and attitude were measured through a seven-point Likert-scale ( $1=$ strongly disagree and $7=$ strongly agree) with three items for religiosity (value) adopted from Bakar, Lee and Hashim (2013) and six items for attitude adopted from Chen and Kong (2009). In section C, the respondents were asked about their gender, age, marital status, occupation, monthly income, educational level, race, religion, family size, work experience and residence. Then, by using purposive sampling technique a pre-test acceptable for the quotation of comments and recommendations from respondents regarding potential defects including the questionnaire format, design, and wording. 


\section{Data Analysis}

The data does not have the normality requirement when it is analyzed with Smart PLS. However, as recommended by Hair et al. (2017), this study was tested for the multivariate normality by looking at the skewness and kurtosis using the software available at: https://webpower.psychstat.org/models/kurtosis/results.php?url=5520c7e5d0ef1285e1b17 $1728 \mathrm{~b} 1 \mathrm{~b} 6641$. If the distribution is normal, the values of skewness and kurtosis are zero. Kurtosis values that are more than zero display a distribution that is too peaked with short, thick tails, and kurtosis values that are low than zero display a distribution that is too flat (also with too many cases in the tails). Non-normal kurtosis demonstrates an underestimate of the variance of a variable (Tabachnick \& Fidell, 2007). The result exhibits that the Mardia"s multivariate skewness $(\beta=5.799, p<0.01)$ and Mardia"s multivariate kurtosis $(\beta=22.903, p$ $<0.01$ ). Hence, the data was slightly not normal and it is appropriate to apply the Smart PLS software in this study. The Partial Least Squares (PLS) analysis (using the SmartPLS 3.2.9 software) was used to analyze the measurement model (Ringle et al., 2015). There are two suggested stage for analytical procedures. First is the measurement model (validity and reliability of boycott (BCT), religiosity (RLG) and attitude (ATT)) (Anderson \& Gerbing, 1988). Second, the examination of the structural model (testing the hypothesized relationship) (Hair et al., 2014). Next, is to test the common method variance (CMV), which disclosed that it should be a problematic issue for the study if the data were collected from a single source (MacKenzie et al., 2011). To overcome the CMV, the study applied the statistical method. For the statistical method, a full collinearity analysis was done. The full collinearity analysis is considered to be a comprehensive procedure for the simultaneous assessment of both vertical and lateral collinearity (Kock \& Lynn, 2012; Kock \& Gaskins, 2014). Table 3 presents the resulting VIF values for all latent variables (boycott participation, religiosity and attitude) in the model that were less than 3.3. Hence, this result confirms that the $\mathrm{CMV}$ is not a serious threat to the study.

\section{Results}

Demographic Profile

As can be seen in Table 1, 238 respondents (72.1\%) were female and the rest $(92,27.9 \%)$ were male. In regards to age, the largest proportion (161) of the respondents (48.3\%) were aged between 20 to 29 years old and this is followed by 64 respondents below 20 years old and only one oldest respondent that aged between 60 years old and above. As indicated in Table 1 , just over half of the respondents were certificate/diploma and Bachelors' Degree holders $(229,69.4 \%)$ and the vast majority of the respondents were Muslim (314, 95.2\%). Furthermore, the largest group of respondents $(201,60.9 \%)$ were student that most of them had no working experience $(126,38.2 \%)$ and no income $(190,57.6 \%)$. Majority, respondents stay at urban area $(257,77.9 \%)$. Finally, the majority of the respondents $(307,93.6 \%)$ belonged to the Malay ethnic group. 
Table 1: Demographic Profile of Respondents $(n=330)$

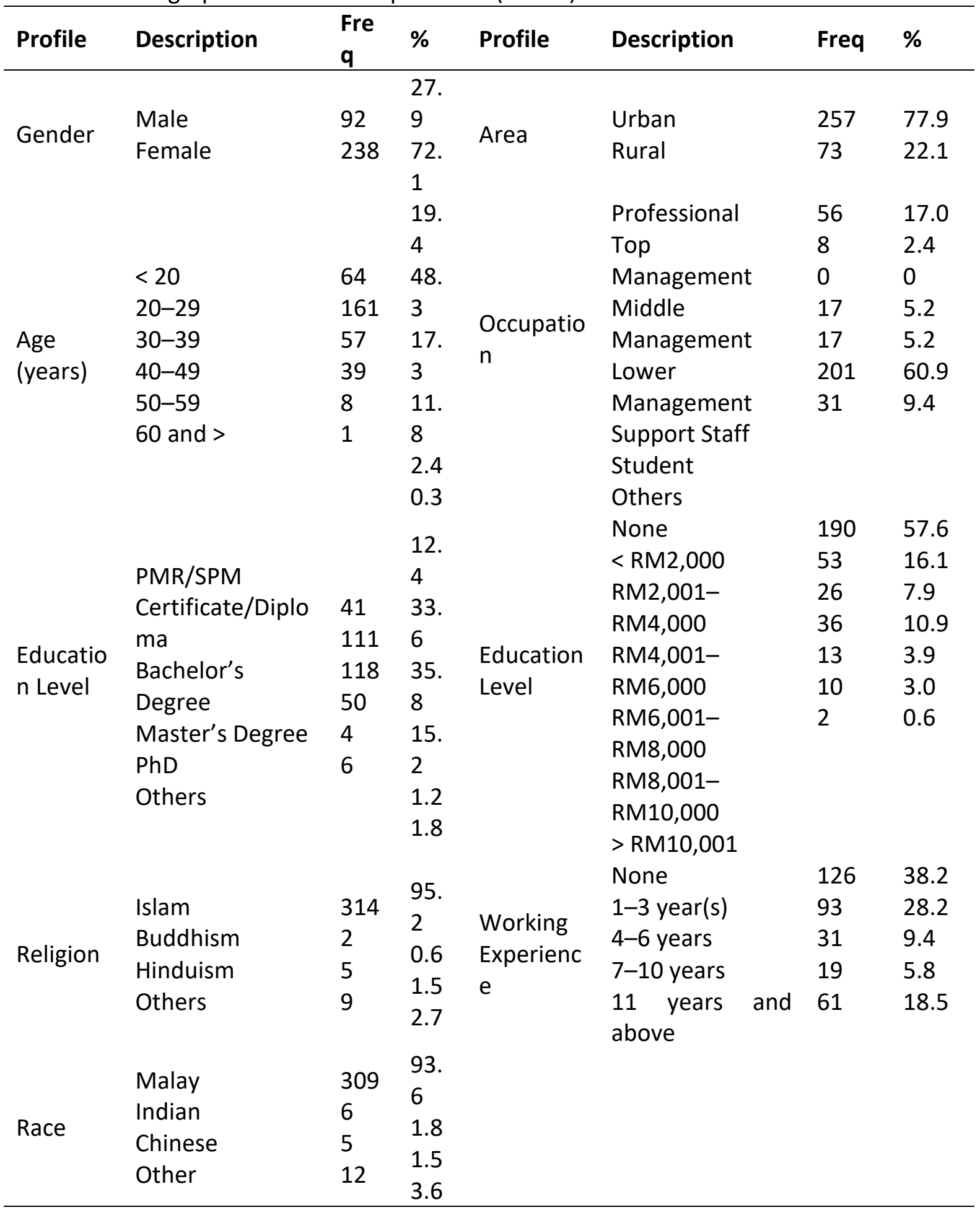

Measurement Model

Under the reflective model, 2 types of validity are assessed: 1) Convergent validity and 2) Discriminant Validity. Convergent validity is the degree to which indicators of a specific constructs converge or shares a high proportion of variance that are in common (Hair et al., 2010, p.771). As suggested by Hair et al. (2017), factor loadings, and AVE are used to assess convergent validity. The indicator loadings, $C R$ and $A V E$ of the reflective constructs are shown in Table 2. All the loadings which exceed the recommended value of 0.5 (Hair et al., 2017) 
are retained. Moreover, all three constructs meet the threshold values/minimum cut-off values for CR and AVE, where all CRs are greater than 0.7 and all AVEs are greater than 0.5 (Hair et al., 2017). Item that did not fulfil the criteria outlined above were deleted from the model such as RLG3. It is concluded that the constructs meet reliability and convergent validity requirement at this stage.

Table 2: Measurement Model

\begin{tabular}{clccc}
\hline Construct & \multicolumn{1}{c}{ Item } & Loading & AVE & CR \\
\hline \multirow{5}{*}{ Attitude } & MED_ATT1 & 0.544 & & \\
& MED_ATT2 & 0.759 & & \\
& MED_ATT3 & 0.679 & 0.502 & 0.856 \\
& MED_ATT4 & 0.768 & & \\
Religiosity & MED_ATT5 & 0.818 & & \\
& MED_ATT6 & 0.651 & & 0.805 \\
& RELG1 & 0.883 & 0.675 & \\
Boycott & RELG2 & 0.756 & & \\
& SRCB_BOC1 & 0.822 & & \\
& SRCB_BOC2 & 0.859 & & \\
& SRCB_BOC3 & 0.808 & 0.550 & \\
\hline
\end{tabular}

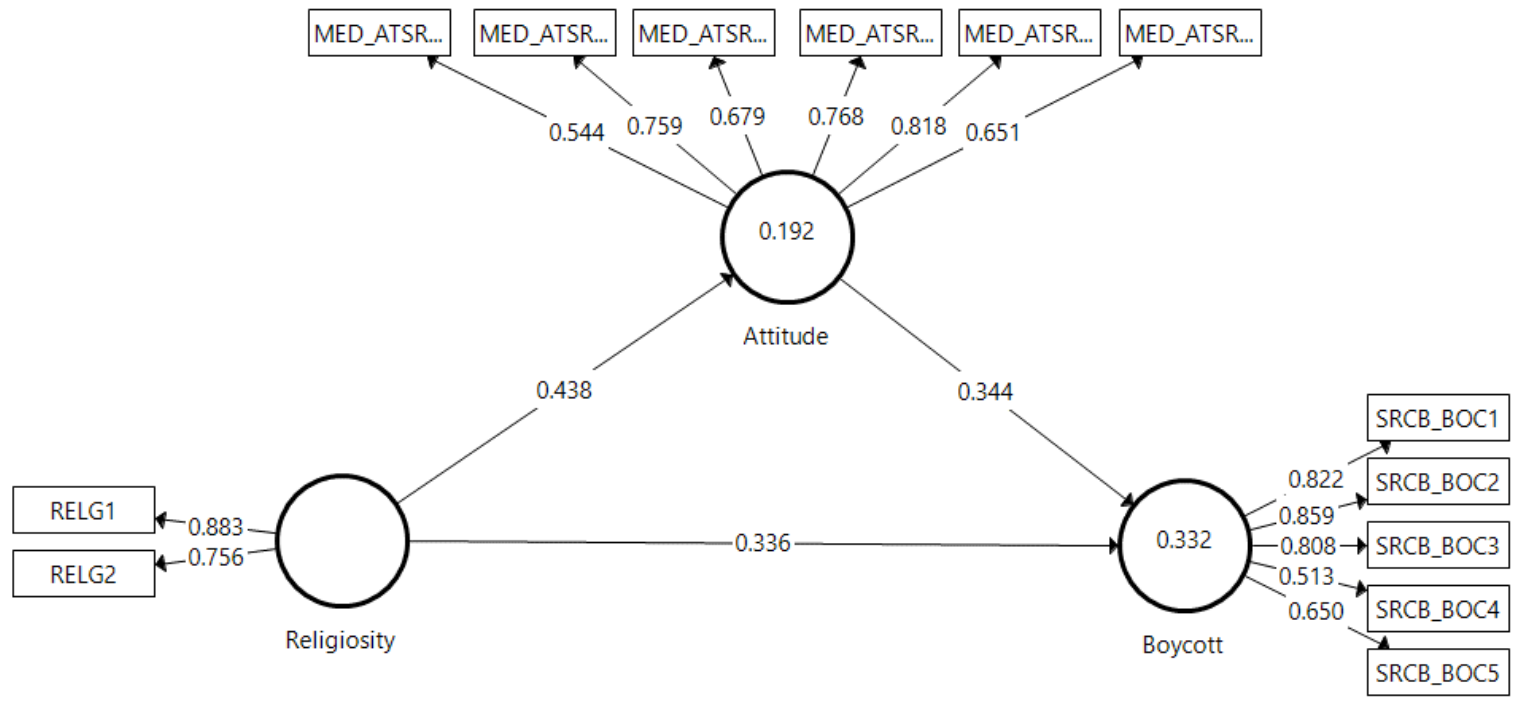

Figure 2: Path analysis result for measurement model

Subsequently, discriminant validity of the model is assessed. Indicators should load more strongly on their own constructs than on others in the model, and the average variance shared between the construct and its measure should be greater than the variance. According to Franke and Sarstedt (2018), the heterotrait-monotrait (HTMT) ratio is a stringent method to confirm the discriminant validity of a study if it made use of Smart PLS. Referring to Franke and Sarstedt (2018), the HTMT ratio is confirmed if the values of all variables in the study are $<0.85$. Since all the HTMT values were lower than 0.85 , it was an indication that the 
discriminant validity was established for the study. Table 3 illustrates the results of the HTMT ratio analysis.

Table 3: Discriminant validity (HTMT ratio)

\begin{tabular}{lccc}
\hline & ATT & BCT & RLG \\
\hline Attitude (ATT) & & & \\
Boycott (BCT) & 0.621 & & \\
Religiosity (RLG) & 0.652 & 0.712 & \\
\hline
\end{tabular}

Prior to evaluating the structural model, it is vital to confirm that there is no lateral collinearity issue in the structural model. All the inner VIF values for all the variables (religiosity, attitude and boycotts) that need to be examined for multicollinearity are less than 3.3 , indicating that the multicollinearity is not a concern in this study (Diamantopoulos \& Siguaw, 2006). In order to analyze the hypotheses of this study, a bootstrapping technique with a resampling of 5000 was applied as proposed by Hair, Sarstedt and Ringle (2019). Based on the assessment of the path coefficient as shown in Table 4, all three relationships are found to have a t-value $>1.645$, thus significant at 0.05 level of significance. Specifically, the predictors of religiosity $(\beta=$ $0.336, p<0.01)$ and attitude $(\beta=0.334, p<0.01)$ are positively related on boycott, which explains $33.2 \%$ of variances in consumer boycotts. Thus, $\mathrm{H} 1$ and $\mathrm{H} 3$ are supported. The $\mathrm{R}^{2}$ value of 0.332 is above the 0.26 value, that indicates that is a substantial model as suggested by Cohen (1998). Next, the result of the effect of attitude on consumer boycotts indicates that attitude $(\beta=0.438, p<0.01)$ is positively related to boycott participation, explaining $19.2 \%$ of the variance in the boycott. This result supports the $\mathrm{H} 2$ of this study. The $\mathrm{R}^{2}$ value of 0.192 is above the 0.13 value that indicates the moderate model as suggested by Cohen (1988). Next, the effect sizes $\left(\mathrm{f}^{2}\right)$ are assessed. To measure the effect size, the Cohen (1988) guideline is used. The values of $0.02,0.15$ and 0.35 represent small, medium and large effects respectively (Cohen, 1988). From Table 4, it can be observed that religiosity has a medium effect in producing the $R^{2}$ for attitude (0.237). Furthermore, the result indicates that religiosity $(0.136)$ and attitude $(0.143)$ have small effects in producing the $\mathrm{R}^{2}$ for boycott.

Table 4: Result of hypotheses testing

\begin{tabular}{|c|c|c|c|c|c|c|c|c|c|c|c|}
\hline \multirow[t]{2}{*}{$\begin{array}{l}\mathbf{N} \\
0\end{array}$} & \multirow[t]{2}{*}{$\begin{array}{l}\text { Path } \\
\text { Model }\end{array}$} & \multirow[t]{2}{*}{$\begin{array}{c}\text { Bet } \\
\text { a }\end{array}$} & \multirow[t]{2}{*}{$\begin{array}{l}\text { Std. } \\
\text { Erro } \\
r\end{array}$} & \multirow[t]{2}{*}{$\begin{array}{c}\mathrm{t}- \\
\text { valu } \\
\mathrm{e}\end{array}$} & \multirow[t]{2}{*}{$\begin{array}{c}\text { p- } \\
\text { Valu } \\
\text { e }\end{array}$} & \multicolumn{2}{|c|}{$\begin{array}{c}\text { Confidence } \\
\text { Interval } \\
\text { (BC) }\end{array}$} & \multirow[t]{2}{*}{$\mathbf{R}^{2}$} & \multirow[t]{2}{*}{$f^{2}$} & \multirow[t]{2}{*}{ VIF } & \multirow[t]{2}{*}{ Result } \\
\hline & & & & & & LL & UL & & & & \\
\hline $\mathrm{H}$ & Religiosity & 0.33 & 0.05 & 5.84 & 0.00 & 0.25 & 0.42 & 0.33 & 0.13 & 1.23 & Support \\
\hline 1 & -> Boycott & 6 & 7 & 5 & 1 & 1 & 9 & 2 & 6 & 7 & ed \\
\hline $\mathrm{H}$ & Religiosity & 0.43 & 0.05 & 7.91 & 0.00 & 0.32 & 0.51 & 0.19 & 0.23 & 1.00 & Support \\
\hline 2 & -> Attitude & 8 & 5 & 1 & 1 & 5 & 0 & 2 & 7 & 0 & ed \\
\hline $\mathrm{H}$ & Attitude -> & 0.34 & 0.05 & 6.35 & 0.00 & 0.24 & 0.43 & & 0.14 & 1.23 & Support \\
\hline 3 & Boycott & 4 & 4 & 3 & 1 & 5 & 3 & & 3 & 7 & ed \\
\hline
\end{tabular}

Shmueli et al (2019) proposed that PLS predict is a hold-out sample-based procedure that generates case-level predictions on an item or a constructs level by using the PLS predict with a 10-fold procedure to check for predictive relevance. Shmueli et al (2019) also suggested that if all the item differences (PLS-LM) were lower than LM, then there was a strong predictive power. If all the item differences are higher than $L M$, then the predictive relevance 
is not confirmed. If the majority of item differences are lower than $L M$, then there is a moderate predictive power. If the minority of item differences are lower than $L M$, then there is a low predictive power. As can be seen in Table 5, the results of the analysis are mixed. Based on guidelines by Shmueli et al. (2019), for attitude, the result of this study showed that the predictive power is moderate, whereas for boycott, the predictive relevance is low.

Table 5: Prediction Summary

\begin{tabular}{lcccc}
\hline \multicolumn{1}{c}{ Item } & $\begin{array}{c}\text { PLS } \\
\text { RMSE }\end{array}$ & $\begin{array}{c}\text { LM } \\
\text { RMSE }\end{array}$ & PLS - LM & $\mathbf{Q}^{\mathbf{2}}$ (PLS) \\
\hline MED_ATT1 & 1.560 & 1.563 & -0.002 & 0.036 \\
MED_ATT2 & 0.871 & 0.871 & 0.000 & 0.171 \\
MED_ATT4 & 1.084 & 1.097 & -0.013 & 0.099 \\
MED_ATT6 & 1.238 & 1.236 & 0.002 & 0.021 \\
MED_ATT5 & 0.879 & 0.884 & -0.005 & 0.146 \\
MED_ATT3 & 1.223 & 1.228 & -0.005 & 0.043 \\
SRCB_BOC2 & 1.293 & 1.279 & 0.015 & 0.146 \\
SRCB_BOC1 & 1.359 & 1.354 & 0.005 & 0.129 \\
SRCB_BOC4 & 1.707 & 1.700 & 0.008 & 0.038 \\
SRCB_BOC5 & 1.715 & 1.706 & 0.009 & 0.118 \\
SRCB_BOC3 & 1.302 & 1.318 & -0.017 & 0.182 \\
\hline
\end{tabular}

For the mediation or indirect effect analysis, the authors followed guidelines prepared by Preacher and Hayes (2008) which proposed bootstrapping in the indirect effect. The result for this study found that attitude mediates the relationship between religiosity and boycott $(\beta=$ $0.151, p<0.01)$, hence $\mathrm{H} 4$ supported.

Table 6: Hypothesis for the mediating variable

\begin{tabular}{|c|c|c|c|c|c|c|c|c|c|}
\hline \multirow[t]{2}{*}{ No } & \multirow{2}{*}{\multicolumn{2}{|c|}{ Path Model }} & \multirow[t]{2}{*}{ Beta } & \multirow{2}{*}{$\begin{array}{l}\text { Std. } \\
\text { erro } \\
r\end{array}$} & \multirow[t]{2}{*}{$\begin{array}{c}\text { t- } \\
\text { valu } \\
e\end{array}$} & \multirow[t]{2}{*}{$\begin{array}{c}\text { p- } \\
\text { valu } \\
e\end{array}$} & \multicolumn{2}{|c|}{$\begin{array}{l}\text { Confidence } \\
\text { Interval } \\
\text { (BC) }\end{array}$} & \multirow[t]{2}{*}{ Result } \\
\hline & & & & & & & UL & LL & \\
\hline $\mathrm{H} 4$ & Religiosity $->$ Attitude & $\rightarrow$ & 0.15 & 0.03 & 4.56 & 0.00 & 0.09 & 0.21 & Supporte \\
\hline$\pi 4$ & Boycott & & 1 & 3 & 4 & 1 & 0 & 7 & $\mathrm{~d}$ \\
\hline
\end{tabular}

\section{Discussion}

In today's market, consumer boycott refers to something that is related to the belief that consumers will use their purchasing power to boycott the target's behaviour as well as the belief that the boycott will succeed in forcing the target to discontinue its egregious behaviour. This study has three main findings. Firstly, the results showed that consumers are willing to boycott when it concerns with the misbehavior of offering the unsafe or unhealthy product. Secondly, the results for this study demonstrated that religiosity positively influences the attitude and boycott. Thirdly, attitude mediates the relationship between religiosity and boycott participation. One possible reason the result showed that religiosity positively influences the boycott participation could be due to the fact that the majority of the respondents in this study are Malays and Muslim. In Malaysia, Malays are usually born as Muslims. Furthermore, the striking use of religiosity appeals in a boycott campaign, and the rising Islamic conservatism among Muslim consumers would place religiosity at the core of the group's motivation and participation in a boycott (Muhammad, Kamarudin \& Fauzi, 2018). 
This study supports previous studies that proposed that religiosity positively influences consumer boycott participation (Al-Hyari et al., 2012; Fakriza \& Nurdin, 2019; \& Farah, 2014). Another key objective of this study was to examine whether attitude mediates the relationship between religiosity and boycott participation and it was examined within the framework of the VAB model. Therefore, the hypothesis in the study is consistent with Homer and Kahle (1988), which posit that from religiosity (value) affects attitude, which in turn to specific behaviors (boycott). This sequence can be described the value attitude behaviour hierarchy.

\section{Conclusions and Recommendations}

Consumer boycotts of brands and manufacturers have become commonplace in today's competitive business environment. Effective boycotts are considered to be one of the most important means by which consumers can induce socially responsible conducts/ethical business practices and put pressure on companies to introduce sustainable developmental actions (Delistavrou et al., 2019; Lavorata, 2014). Yet, CSR and consumer behaviour literature have not paid attention on the rising severity of consumer boycotts. Thus, the literature on this issue is rather limited. Understanding the effect of religiosity and attitude on consumer boycotts would therefore enhances understanding on factors impacting consumer boycotts as wells as how these factors (i.e., religiosity and attitude) impact consumer boycotts. This study establishes that religiosity and attitude have positive impacts on consumer boycotts. In addition, this study confirms the mediating role of attitude in the relationship between religiosity and consumer boycotts. The findings provide support for the VAB model.

This study provides several theoretical and managerial contributions. For theoretical implications, this study contributes to the literature on consumer boycotts in the context of developing countries. Moreover, this study has shown the significant influence of religiosity and attitudes on consumer boycotts among consumers in Malaysia. This study extends the study conducted by Farah (2014) in that this study examined boycott behaviour instead of boycott intention. In addition, this study also extends the study conducted by Dekhil et al. (2015) in such a way that this study examines the mediating role of attitudes on the relationship between religiosity and consumer boycotts. From a managerial perspective, this study provides CSR managers, boycott organizers as well as policy makers with information on how to manage consumer boycotts. Moreover, this study proposes a tool for measuring ability to participate in boycotts for sustainable development as perceived by consumers. This will allow companies to determine what action they need to take to incorporate sustainable development into their practice. While it seems exciting for companies to know determinants of consumer boycotts, the findings suggest that religiosity and attitudes play important roles in consumer boycotts. First, managers need to take note that although some consumer boycotts are punitive in nature, many are not. Therefore, companies need to rethink and transform their business model towards more sustainable business models that are free from unethical business practices such as producing unsafe and unhealthy products, exploitations of human and animal rights, environmental degradation, etc. This will enhance consumers' attitude towards companies' products and services. Second, companies should improve the overall marketing mix to enhance consumers' attitudes, satisfaction and loyalty towards companies' products and services. This will diminish the impact of religiosity and attitude on boycotts. 
This study is not immune to some limitations. First, although the study establishes that religiosity and attitude have positive impacts on consumer boycotts. There are other factors that also contribute towards consumer boycotts. For instance, the effect of social media and social norms on consumer boycotts warrants further investigation. Additionally, whilst this study establishes the mediating role of attitude, there remain other mediating factors that may also affect the relationship between religiosity and consumer boycotts. Second, this study uses an online survey. Future study may employ in-depth interviews in order to gain detailed information regarding the reason why consumers are willing to boycott certain products from certain countries and/or companies. This sampling technique is also more appropriate to be used in identifying the religiosity factor in an in-depth manner because this factor is quite sensitive and the respondents may want to share and explain in detail why they get involved with boycott. Moreover, using an in-depth interview provides a richer and detail responses on how other factors affect consumer boycotts would also be further revealed, it may be suitable to.

\section{Acknowledgement}

The authors would like to thank Universiti Malaysia Terengganu and Universiti Teknologi MARA in supporting this research.

\section{References}

Abosag, I. (2010). "Dancing with macro-boycotters: the case of Arla Food". Journal of Marketing Planning and Intelligence, Vol. 28, No.3, pp. 365-373.

Abdul-Talib, A. N., Abd-Latif, S. A., \& Abd-Razak, I. S. (2016). A study on the boycott motivations of Malaysian non-Muslims. Journal of Islamic Marketing

Abd-Razak, I. S., \& Abdul-Talib, A-N. (2012). Globality and internationality attribution of animosity. Journal of Islamic Marketing, 3(1), $72-80$. http://dx.doi.org/10.1108/17590831211206608

Abou-Youssef, M. M. H., Kortam, W., Abou-Aish, E., \& El-Bassiouny, N. (2015). Effects of religiosity on consumer attitudes toward Islamic banking in Egypt. International Journal of Bank Marketing, 33(6), 786-807. https://doi.org/10.1108/IJBM-02-20150024

Al-Hyari, K., Alnsour, M., Al-Weshah, G., \& Haffar M. (2012). "Religious beliefs and consumer behaviour: from loyalty to boycotts". Journal of Islamic Marketing, Vol. 3, No: 2, pp.155-174.

Anderson, J. C., \& Gerbing, D. W. (1988). Structural equation modeling in practice: A review and recommended two-step approach. Psychological Bulletin, 103(3), 411-423.

Armstrong, K. (2001). Battle for God: A History of Fundamentalism, Ballantine Books, New York, NY.

Arnould, E., Price, L., \& Zikhan, G. (2004). Consumers, 2nd ed., McGraw Hill, New York, NY.

Burkett, S.R. (1980). "Religiosity, beliefs, normative standards and adolescent drinking", Journal of Studies on Alcohol, Vol. 41, No. 7, pp. 662-671.

Bakar, A., Lee, R., \& Hashim, N. H. (2013). Parsing religiosity, guilt and materialism on consumer ethics. Journal of Islamic Marketing, 4(3), 232-244. http://dx.doi.org/10.1108/JIMA-04-2012-0018.

Chen, K., \& Kong, Y., (2009). Chinese consumer perceptions of socially responsible consumption. Social Responsibility Journal. 5(2), 144-151.

DOI10.1108/17471110910964441 
Cohen, J. (1988). Statistical Power Analysis for the behavioural science ( $2^{\text {nd }}$ ed.). Hillsdale, NJ: Lawrence Erlbaum Associates.

Cochran, K., \& Cohen, P. (1983). Applied multiple regression/correlation analysis for the behavioral sciences, 2nd ed., Lawernce Erlbaum.

Delener, N. (1994). Religious contrasts in consumer decision behavior patterns: their dimensions and marketing implications. European Journal of Marketing, Vol. 28, No. 5, pp. 36-53.

Dekhil, F., Jridi, H., \& Farhat, H. (2017). "Effect of religiosity on the decision to participate in a boycott: The moderating effect of brand loyalty - the case of Coca-Cola". Journal of Islamic Marketing, Vol. 8 No. 2, pp. 309-328. https://doi.org/10.1108/JIMA-01-20130008

Delistavrou, A., Tilikidou, I., \& Krystallis, A. (2020). Consumers' decision to boycott "unethical" products: The role of materialism/post materialism. International Journal of Retail and Distribution Management, 48(10),1121-1138. https://doi.org/10.1108/IJRDM-042019-0126

Diamantopoulos, A., \& Siguaw, J. A. (2006). Formative versus reflective indicators in organizational measure development: A comparison and empirical illustration, British Journal of Management, 17(4), 263-282.

Fam, K. S., Waller, D. S., \& Erdogan, Z. B. (2004). The influence of religion on attitudes towards the advertising of controversial products. European Journal of Marketing, 38, 537555.

Farah, M. F. (2014). An Expectancy-Value Approach to the Study of Beliefs Underlying Consumer Boycott Intention. International Journal of Business and Management, Vol. 9, No. 10. URL: http://dx.doi.org/10.5539/ijbm.v9n10p101

Fakriza, R., \& Nurdin, R. (2019). Pengaruh religiusitas terhadap boikot dengan loyalitas merek sebagai variabel moderasi pada KFC Banda Aceh. Jurnal Ilmiah Mahasiswa Ekonomi Manajemen. 4(1):206-216

Fazio, R. H. (1986). How do attitudes guide behavior, in Sorrentino, R.M. and Higgins, E.T. (Eds), Handbook of Motivation and Cognition: Foundations of Social Behavior, The Guilford Press, New York, NY.

Franke, G., \& Sarstedt, M. (2019), "Heuristics versus statistics in discriminant validity testing: a comparison of four procedures", Internet Research (forthcoming)

Friedman, M. (1999), Consumer Boycotts, New York: Routledge.

Gaskins, L., \& Kock, N. (2014). The mediating role of voice and accountability in the relationship between internet diffusion and government corruption in Latin America and Sub-Sahara Africa. Information Technology for Development. 20 (1): 23-43, http://dx.doi.org/10.1080/02681102.2013.832129

Hawks, R. D., \& Bahr, S. H. (1992). Religion and drug use. Journal of Drug Education. 22(1): 18.

Hair, J. F., Sarstedt, M., \& Ringle, C. M. (2019), "Rethinking some of the rethinking of partial least squares", European Journal of Marketing (forthcoming).

Hoffmann, S., \& Múller, S. (2009). Consumer boycotts due to factory relocation. Journal Business Res;62(2):239-47.

Holmes, P. (2005). More Than a Third of World's Consumers Boycott Brands. Provoke. https://www.provokemedia.com/latest/article/more-than-a-third-of-world'sconsumers- boycott-brands. Retrieved 17 December 2020 
Homer, P. M., \& Kahle, L. R. (1988). A structural equation test of the values-attitude-behaviour hierarchy. Journal of Personality and Social Psychological, 54(4), 638-646.

Honkanen, P., Verplanken, B., \& Olsen, S. O. (2006). Ethical values and motives driving organic food choice. Journal of Consumer Behaviour, 5(5), 420-430. doi:10.1002/cb.190

Hulland, J., Baumgartner, H., \& Smith, K. M. (2017). Marketing survey research best practices: evidence and recommendations from a review of JAMS articles. Journal of the Academy of Marketing Science, 1-17. doi: 10.1007/s11747-017-0532-y

Jensen, H. R. (2008), "The Mohammed Cartoons Controversy and the Boycott of Danish Products in the Middle East," European Business Review, 20 (3), 275-89.

Kang, J., Jun, J., Arendt, S. W. (2015). Understanding customers' healthy food choices at casual dining restaurants: Using the Value-Attitude-Behavior model. International Journal of Hospitality Management. 48; 12-21. https://doi.org/10.1016/j.ijhm.2015.04.005

Kantar. (2019). Consumers are punishing brands for their environmental track record. WARC. https://www.warc.com/newsandopinion/news/consumers-are-punishing-brandsfor- their-environmental-track-record/42989

Kock, N., \& Gaskins, L. (2014). The mediating role of voice and accountability in the relationship between internet diffusion and government corruption in Latin America and Sub-Saharan Africa. Information Technology for Development, 20(1); 23-43, http://dx.doi.org/10.1080/02681102.2013.832129

Kock, N., \& Lynn, G. S. (2012). Lateral Collinearity and Misleading Results in Variance-Based SEM: An Illustration and Recommendations. Journal of the Association for Information Systems. 13(7): 546-580

Koening, H. G., McCullough, M., \& Larson, D. B. (2000). Handbook of religion and health, Oxford University Press, New York.

Klein, J., Smith, C., \& John, A. (2004), "Why we boycott: consumer motivations for boycott participation". Journal of Marketing, 68(3), 921-109.

Lavorata, L. (2014). Influence of retailers' commitment to sustainable development on store image, consumer loyalty and consumer boycotts: Proposal for a model using the theory of planned behavior. Journal of Retailing and Consumer Services, 21(6), 10211027. https://doi.org/10.1016/j.jretconser.2014.01.003

Lee, M. S. W., Motion, J., \& Conroy, D. (2009). Anti-consumption and brand avoidance. Journal Business Res;62(2):169-80.

Luo, X. R., Zhang, J., \& Marquis, C. (2016). Mobilization in the Internet Age: Internet Activism and Corporate Response. Academy of Management Journal, 59(6), 2045-2068. doi:10.5465/amj.2015.0693

MacKenzie, S. B., Podsakoff, P. H., \& Podsakoff, N. P. (2011). Construct measurement and validation procedures in mis and behavioral research: integrating new and existing techniques ${ }^{1}$. MIS Quarterly , 35 (2), 293-334

Malaysia Official Statistic. (2020). http://www.statistics.gov.my/portal/index. (Retrieved, 1 January, 2021)

Matitila, A. S., Apostolopoulos, Y., Sonmez, S., Yu, L., \& Sasidharan, V. (2001)., "The impact of gender and religion on college student's spring break behavior". Journal of Travel Research, Vol. 40, No. 2, pp. 193-200.

Muhamad, N., Khamarudin, M., \& Fauzi, W. I. M. (2018). The role of religious motivation in an international consumer boycott. British Food Journal. doi:10.1108/bfj-02-2018-0118 
Omar, N., Nazri, M., Zainol, Z., Ali, M., \& Alam, S. (2019). Perceived severity of halal violation: CSR and consumer boycott. The South East Asian Journal of Management, 13(2), 183200

Peterson, L. R., \& Roy, A. (1985). "Religiosity, anxiety, and meaning and purpose: Religion's consequences for psychological wellbeing." Review of Religious Research 27: 49-62.

Pettinger, C., Holdsworth, M., \& Gerber, M. (2004), "Psycho-social influences on food choise in southern France and central England". Appetite, Vol. 42, No. 3, pp. 307-316.

Preacher, K. J., \& Hayes, A. F. (2008). Asymptotic and resampling strategies for assessing and comparing indirect effects in multiple mediator models. Behavior Research Methods, 40(3), 879-891.

Regencia, T. (2019). Muslims urged to boycott Chinese products over Uighur 'abuses'. https://www.aljazeera.com/news/2019/12/muslim-boycott-chinese-products-urgeduighur-treatment-191220122039763.html. Retrieved on 23 December 2019.

Ringle, C. M., Wende, S., \& Becker, J. M. (2015). SmartPLS 3.

Safak, Y. (2019). World must boycott China's 2022 Winter Olympics over Muslim Uyghur abuse. https://www.yenisafak.com/en/world/world. Retrieved on 15 December 2020.

Sarstedt, M., Ringle, C. M., Cheah, J.H., Ting, H., \& Moisescu, O. I. (2019). Structural model robustness checks in PLS-SEM. Tourism Economics 1(24); 1-24. https://doi.org/10.1177/1354816618823921

Sasson, T. (2016). Milking the third world? Humanitarianism, capitalism, and the moral economy of the Nestlé boycott. The American Historical Review, 121(4), 1196-1224. https://doi.org/10.1093/ahr/121.4.1196.

Sen, S., Gurhan-Canli, Z., \& Morwitz, V. (2001), "Withholding consumption: A social dilemma perspective on consumer boycotts", Journal of Consumer Research, Vol. 28, No. 4, pp. 399-417.

Schiffman, L., \& Kanuk, L. (2000). Consumer Behavior, 7th ed., Prentice Hall, New York, NY.

Shaw, D., \& Newholm, T. (2002). Voluntary simplicity and the ethics of consumption. Psychology and Marketing, 19(2), 167-185. https://doi.org/10.1002/mar.10008

Shmueli, G., Sarstedt, M., Hair, J. F., Cheah, J.-H., Ting, H., Vaithilingam, S., \& Ringle, C. M. (2019), "Predictive model assessment in PLS-SEM: guidelines for using PLSpredict", European Journal of Marketing, 53(11), pp. 2322-2347. https://doi.org/10.1108/EJM02-2019-0189

Stolz, J. (2009). Explaining religiosity: towards a unified theoretical model1. The British Journal of Sociology, 60(2), 345-376. doi:10.1111/j.1468-4446.2009.01234.x

Strahilevitz, M. (2003). The Effects of Prior Impressions of a Firm's Ethics on the Success of a Cause-Related Marketing Campaign: Do the Good Look Better While the Bad Look Worse? Journal of Nonprofit \& Public Sector Marketing, 11(1), 77-92. doi:10.1300/j054v11n01_06

Tabachnick, B. G., \& Fidell, L. S. (2007). Using Multivariate Statistics. United States of America: Pearson Education. Inc

Tee, K. (2020). Ummah calls for nationwide boycott of French goods, services after Macron's 'anti-Islam' comments. Malay Mail.

https://www.malaymail.com/news/malaysia/2020/11/01/ummah-calls-fornationwide-boycott-of-french-goods-services-after-macrons-a/1918364. (Retrieved, 1 January, 2021).

Vaske, J. J., \& Donnelly, M. P. (1999). A value-attitude-behaviour model predicting wildland preservation voting intentions. Society \& Natural Resources. 12: 523-537 
Villanueva, J. (2020). The dark side of brand boycotts. Forbes. https://www.forbes.com/sites/julianvillanueva/2020/07/21/the-dark-side-of-brandboycotts/?sh=1ec8d49962ca. Retrieved 30 Disember 2020.

Wexler, J. (2021). Still trapped in poverty. Ethical Consumer Magazine, issue 188, Jan/Feb 2021. RAP Spideweb Ltd. ISSN 0955-8608

Yang, J., \& Rhee, J. H. (2020). CSR disclosure against boycotts: evidence from Korea. Asian Bussiness Management, 311-343. https://doi.org/10.1057/s41291-019-00063-5

Yuksel, U. (2013). Non-participation in anti-consumption: Consumer reluctance to boycott. Journal of Macromarketing, 33(3), 204-216.

Yuksel, U., \& Mryteza, V. (2009). An evaluation of strategic responses to consumer boycotts. Journal of Business Research, 62(2), 248-259.

Zeng, T., Audrain-Pontevia, A., \& Durif, F. (2020). Does corporate social responsibility affect consumer boycotts? A cost-benefit approach. Corporate Social Responsibility and Environmental Management. doi:10.1002/csr.2089 
Appendix 1: Research Instrument

\begin{tabular}{|c|c|c|c|}
\hline Variable & Coding & Statement & $\begin{array}{c}\text { Author(s) and } \\
\text { Year }\end{array}$ \\
\hline \multirow{5}{*}{ Boycott } & SRCB_BOC1 & $\begin{array}{l}\text { BOC1 I keep on boycotting unsafe } \\
\text { products. }\end{array}$ & \multirow{5}{*}{$\begin{array}{l}\text { Farah (2014) } \\
\text { Six items } \\
\text { scored on } \\
\text { seven-point } \\
\text { Likert scale }\end{array}$} \\
\hline & SRCB_BOC2 & $\begin{array}{l}\text { BOC2 I keep on boycotting } \\
\text { unhealthy products. }\end{array}$ & \\
\hline & SRCB_BOC3 & $\begin{array}{l}\text { BOC3 I boycott products from } \\
\text { companies that support } \\
\text { inhumane activities. }\end{array}$ & \\
\hline & SRCB_BOC4 & $\begin{array}{l}\text { BOC4 I do not boycott companies } \\
\text { that have a bad reputation } \\
\text { because it limits my product } \\
\text { choices. }\end{array}$ & \\
\hline & SRCB_BOC5 & $\begin{array}{l}\text { BOC5 I boycott companies with a } \\
\text { bad reputation in order to } \\
\text { express my anger at them. }\end{array}$ & \\
\hline \multirow{3}{*}{ Religiosity } & RELG1 & $\begin{array}{l}\text { RELG1 I try hard to live my life } \\
\text { according to my religious beliefs }\end{array}$ & \multirow{3}{*}{$\begin{array}{c}\text { Bakar, Lee and } \\
\text { Hashim (2013) } \\
\text { Three items } \\
\text { scored on a } \\
\text { seven-point } \\
\text { Llikert scale }\end{array}$} \\
\hline & RELG2 & $\begin{array}{l}\text { RELG2 My whole approach to life } \\
\text { is based on my religion. }\end{array}$ & \\
\hline & RELG3 & $\begin{array}{l}\text { RELG3 I often have a strong sense } \\
\text { of God's presence. }\end{array}$ & \\
\hline \multirow{6}{*}{ Attitude } & MED_ATT1 & $\begin{array}{l}\text { ATT1 I know about corporate } \\
\text { social responsibility. }\end{array}$ & \multirow{6}{*}{$\begin{array}{c}\text { Chen and Kong } \\
\text { (2009) } \\
\text { Six items } \\
\text { scored on a } \\
\text { seven-point } \\
\text { Likert scale }\end{array}$} \\
\hline & MED_ATT2 & $\begin{array}{l}\text { ATT2 I think a company should be } \\
\text { responsible. }\end{array}$ & \\
\hline & MED_ATT3 & $\begin{array}{l}\text { ATT3 The socially responsible } \\
\text { performance of a company } \\
\text { influences my purchase. }\end{array}$ & \\
\hline & MED_ATT4 & $\begin{array}{l}\text { ATT4 I think a responsible } \\
\text { company will have a stronger } \\
\text { production power capacity. }\end{array}$ & \\
\hline & MED_ATT5 & $\begin{array}{l}\text { ATT5 I think a responsible } \\
\text { company will have a good } \\
\text { reputation. }\end{array}$ & \\
\hline & MED_ATT6 & $\begin{array}{l}\text { ATT6 I think a company should } \\
\text { disclose information on social } \\
\text { responsibility. }\end{array}$ & \\
\hline
\end{tabular}

